\title{
From Plausibility to Clarity: An Analysis of the Implications of Ashcroft v. Iqbal and Possible Remedies
}

\begin{abstract}
"The sole exception to th[e] rule [that a court must take the allegations as true, no matter how skeptical the court may be] lies with allegations that are sufficiently fantastic to defy reality as we know it: claims about little green men, or the plaintiff's recent trip to Pluto, or experiences in time travel."
\end{abstract}

-Justice Souter ${ }^{1}$

\section{INTRODUCTION}

Providing citizens access to the judicial system is a core principle of democracy. ${ }^{2}$ In a civil action, access to the courts begins with the plaintiff's filing of a complaint. ${ }^{3}$ To this end, for nearly fifty years our nation's courts embraced a simplified concept of pleading that rests on providing the adverse party "notice" of the allegations against them. However, the United States Supreme Court raised the pleading standard from "notice" to something more than "notice" in recent years.

In a 2007 class action antitrust case, Bell Atlantic Corp. v. Twombly, ${ }^{4}$ the Supreme Court addressed pleading requirements in federal court and overruled the well established standard enunciated in a 1957 case, Conley v. Gibson - that "a complaint should not be dismissed for failure to state a claim unless it appears beyond doubt that the plaintiff can

\footnotetext{
* Ryan Mize. J.D. candidate 2011, University of Kansas School of Law. Thank you to Professor Laura Hines, Andy Coleman, and Chris Kaufman, for their helpful comments and suggestions during the writing and editing process. I would also like to acknowledge Tim Davis, Andrea Morrow, Andrew Treaster, and the rest of the Kansas Law Review board and staff for their talent, hard work, and assistance. Lastly, I would like to thank my family for their love, support, and encouragement.

1. Ashcroft v. Iqbal, 129 S. Ct. 1937, 1959 (2009) (Souter, J., dissenting).

2. A. Benjamin Spencer, Understanding Pleading Doctrine, 108 MicH. L. REV. 1, 2 (2009); see also Phillips v. County of Allegheny, 515 F.3d 224, 230 (3d Cir. 2008) (noting that "[f]ew issues in civil procedure jurisprudence are more significant than pleading standards, which are the key that opens access to courts").

3. See FED. R. CIV. P. 8(a)

4. 550 U.S. 544 (2007).
} 
prove no set of facts ... which would entitle him to relief." ${ }^{5}$ Conley was the seminal case clarifying "notice pleading," a concept long understood to be the intent of the Federal Rules of Civil Procedure ("Federal Rules"), adopted twenty years earlier in $1938 .{ }^{6}$ Abandoning Conley, the Court in Twombly applied a confusing "plausibility standard" of pleading, ${ }^{7}$ dismissing the class of plaintiffs' allegations of Sherman Act violations by four telecommunication companies. ${ }^{8}$

Less than one month after Twombly, the Supreme Court in Erickson v. Pardus applied Federal Rule of Civil Procedure 8(a)(2) in traditional fashion, citing the "fair notice" standard enunciated in Conley." Although Erickson involved a pro se prisoner alleging civil rights violations, ${ }^{10}$ a vastly different situation than Twombly, the opinion's significance was its citation of Conley and its "no set of facts" standard after Twombly. However, any speculation about the significance of the Court's reliance on Conley was unwarranted because courts have historically scrutinized pro se prisoners under a lower standard. ${ }^{11}$ Thus, the applicability of the Twombly standard remained speculative and confusing for the judiciary, practitioners, and scholars. ${ }^{12}$ There was much uncertainty about whether the Twombly standard would be limited to the antitrust context and how judges would define plausibility, or more generally, interpret and react to this decision. Such uncertainty was alleviated by the extension of the plausibility standard to a civil rights claim, and indeed all civil claims, in the Supreme Court's controversial Ashcroft v. Iqbal ${ }^{13}$ decision last term. However, alleviating confusion should not be confused with better serving the interests of justice.

5. Conley v. Gibson, 355 U.S. 41, 45-46 (1957), abrogated by Bell Atl. Corp. v. Twombly, 550 U.S. 544 (2007).

6. See FED. R. CIV. P. 8(a); see also A. Benjamin Spencer, Plausibility Pleading, 49 B.C. L. REV. 431, $434 \mathrm{n} .24$ (2008) (reinforcing the articulated purpose of providing notice in pleadings).

7. Twombly, 550 U.S. at 564

8. Id. at $566-70$.

9. Erickson v. Pardus, 551 U.S. 89, 93 (2007).

10. Id. at $89-94$.

11. Spencer, supra note 6 , at 456 .

12. See, e.g., Keith Bradley, Pleading Standards Should Not Change After Bell Atlantic v. Twombly, 102 Nw. L. REV. COLLOQUY 117, 117 (2007) (noting that "plausibility" is antitrust jargon and applying it outside of that context is a misreading of Twombly); Spencer, supra note 2, at 1 (noting that Bell Atlantic "has not left courts and litigants with a clear or precise understanding of what it takes to state a claim that can survive a motion to dismiss"); Scott Dodson, Essay, Pleading Standards After Bell Atlantic v. Twombly, 93 VA. L. REV. IN BRIEF 135, 138 (2007), available at http://www.virginialawreview.org/inbrief/2007/07/09/dodson.pdf (asking "[w]hat does Bell Atlantic really mean?").

13. 129 S. Ct. 1937 (2009). 
The broadened application of Twombly has received mixed reviews in the legal community. Some view the decision as an unwarranted extension of the plausibility doctrine in the face of other fairly recent Supreme Court decisions that upheld a "notice" pleading standard in civil rights actions. ${ }^{14}$ To others, the decision represents a justified and long overdue expansion of "heightened" pleading that will not render defendants helpless when faced with discovery costs imposed by futile complaints, particularly in the realm of complex litigation. Most agree, however, that it represents a substantial shift away from the traditional liberal "notice" pleading standard. Justice Souter, author of Twombly, reveals the juxtaposition of the two cases in the quote from his Iqbal dissent cited at the beginning of this Comment.

Some view Iqbal as the most consequential decision of the 20082009 term and possibly the most important in a decade for "day-to-day" litigation. ${ }^{15}$ The controversial ruling has even instigated legislative responses with the introduction of the Notice Pleading Restoration Act of $2009^{16}$ and the Open Access to Courts Act of 2009. ${ }^{17}$ Both pieces of legislation seek to undo the Twombly-Iqbal standard and reinstate the Conley standard for Rule 12(b)(6) motions. ${ }^{18}$ Rule 12(b)(6) is the impetus for judicial rulings on the sufficiency of a complaint as it allows a party to move to dismiss for "failure to state a claim upon which relief can be granted."19

In the wake of Iqbal, the current pleading standard is likely a product of the increasing complexity of society, industry, and the justice system in general. Within the federal judicial system, the frequency and intensity of complex litigation has vastly multiplied with large-scale toxic torts, products liability, conspiracy claims, and civil rights suits. The discovery and case management issues that accompany such

14. See Swierkiewicz v. Sorema N.A., 534 U.S. 506, 512 (2002) (“[I]mposing... [a] heightened pleading standard in employment discrimination cases conflicts with Federal Rule of Civil Procedure 8(a)(2), which provides that a complaint must include only 'a short and plain statement of the claim showing that the pleader is entitled to relief."'); Leatherman v. Tarrant County Narcotics Intelligence \& Coordination Unit, 507 U.S. 163, 168 (1993) ("We think that it impossible to square the 'heightened pleading standard' applied by the Fifth Circuit in this case with the liberal system of 'notice pleading' set up by the Federal Rules.").

15. Adam Liptak, 9/11 Case Could Bring Broad Shift on Civil Suits, N.Y. TimES, July 21, 2009, available at $\mathrm{http}: / / \mathrm{www} . n y t i m e s . c o m / 2009 / 07 / 21 / \mathrm{us} / 21$ bar.html.

16. The Notice Pleading Restoration Act of 2009, S. 1504, 111th Cong. § 2 (2009) (introduced by Senator Arlen Specter on July 22, 2009 and co-sponsored by Senator Russ Feingold, the bill has been referred to the Senate Judiciary Committee).

17. The Open Access to Courts Act of 2009, H.R. 4115, 111th Cong. § 2 (2009) (introduced by Representative Jerrold Nadler and co-sponsored by eighteen other members of Congress).

18. See id.; S. 1504.

19. FED. R. CIV. P. 12(b)(6). 
litigation were part of the thrust behind the Twombly decision and its extension in Iqbal.

This Comment will examine the confusion and controversy surrounding current pleading standards in federal court, demonstrate the need for change, and propose that, ultimately, the best way to resolve the issue is by amending the Federal Rules to enable complainants bringing particular causes of action to have access to "phased discovery" that allows for equitable screening of cases for lack of merit. Legislation setting forth claim-specific standards is a compelling alternative should amending the Federal Rules prove unlikely. This Comment will examine the implications of Iqbal and consider various judicial and legislative alternatives that could remedy the case's negative consequences. The practical effect of the "plausibility" pleading standard after Iqbal is to depart with traditional notice pleading and require factual allegations that are more than just consistent with impropriety. This requires a plaintiff to have a more stringent factual background than is typical under "notice" pleading. One way or another, modern pleading needs reform on some level.

Part II of this Comment will discuss the background of notice pleading through a brief discussion of the history and adoption of the "modern" pleading standard in Rule 8. An account of the general scrutiny that notice pleading has undergone in various legal areas will be described to provide context for the decisions in Twombly and Iqbal. A review of the facts, reasoning, and holdings of Twombly and Iqbal will follow.

Part III will explain how the Iqbal standard's lack of precision creates problems for the judicial system and will reveal the need for clarification. It will also note actual and potential implications of Iqbal's extension of the plausibility standard to all civil actions in federal court. An analysis of the decision's impact on removal, state law, affirmative defense pleading, and litigants' choice of forum will follow. Having established the need for a remedy, possible courses of action by both the judicial and legislative bodies will then be examined and their advantages and disadvantages assessed. The judicial and legislative alternatives are those aiming to accomplish one or more of five things: (1) judicially clarify plausibility; (2) judicially utilize current Federal Rules that enable fair case management and screening of claims; (3) legislatively specify pleading standards for specific claims; (4) amend the Federal Rules to include claim-specific standards; or (5) amend the Federal Rules to include a uniform standard that somehow accommodates the discovery and case management complexities of modern civil litigation. This Comment will conclude by recommending 
that, absent a clarification of the current standard that would cease denying individuals with meritorious claims access to courts, amending the Federal Rules to grant judges increased pretrial ability to manage potentially meritorious cases is a viable remedy for the pleading problem. Alternatively, legislation that creates claim-specific standards would alleviate the cost and efficiency concerns present in Twombly and Iqbal, while making courts and rulemakers rethink the application of the heightened standard.

\section{BACKGROUND}

\section{A. The Origin of Notice Pleading}

Federal Rule of Civil Procedure 8 is the foundation of the federal pleading system. Prior to the adoption of the Federal Rules in 1938, pleading was a technical endeavor that "served four functions: (1) providing notice of the nature of a claim or defense; (2) identifying baseless claims; (3) setting each party's view of the facts; and (4) narrowing the issues." 20 Modern pleading is only expected to execute the first function. ${ }^{21}$ Thus, the reform executed by the adoption of the Federal Rules represented an effort to diverge from judgments on the pleadings and merely require plaintiffs to provide "notice." The drafters desired a judicial system that would not place undue emphasis on the form and substance of the pleading or value technicality over the merits of the claim. ${ }^{22}$ Rule $8(\mathrm{a})(2)$ reflects this end by requiring that a complaint contain "a short and plain statement of the claim showing that the pleader is entitled to relief." 23 Charles Clark, principal architect of the original Federal Rules, was instrumental in abolishing the need for hyper-technical scrutiny of pleadings, believing a claim's merits should be fleshed out in discovery, summary judgment, or trial. ${ }^{24}$

Until the Supreme Court first addressed the Rule 8(a)(2) standard in Conley, there had been some resistance by courts to the simplified

20. Jack H. Friedenthal et al., Civil Procedure: Cases and Materials 513 (9th ed. 2008 rev.).

21. Id.

22. Christopher M. Fairman, The Myth of Notice Pleading, 45 ARIz. L. REV. 987, 990-91 (2003).

23. FED. R. CIV. P. 8(a)(2).

24. Robert G. Bone, Twombly, Pleading Rules, and Regulation of Court Access, 94 Iowa L. REv. 873, 891-92 (2009) (citing Richard L. Marcus, The Revival of Fact Pleading Under the Federal Rules of Civil Procedure, 86 CoLuM. L. REV. 433, 439-40 (1986)). 
system of pleading the Federal Rules promulgated. ${ }^{25}$ As already mentioned, Conley's "no set of facts" language reigned as the prevailing standard for over fifty years until Twombly recently overruled it. Conley concerned a class action by African-American railway employees who were union members and had been demoted or fired by the railway, which stated that the positions had been abolished. ${ }^{26}$ In actuality, the jobs were not eliminated, but filled by whites or refilled by blacks in a demoted capacity as the petitioners were laid off. ${ }^{27}$ The black employees alleged that the union failed to represent them equally and in good faith, in violation of the Railway Labor Act. ${ }^{28}$ The union moved to dismiss on three grounds, one being for failure to state a claim upon which relief can be granted. ${ }^{29}$ In adjudicating that motion, the Court applied the "no set of facts" standard to rule petitioners' allegations of concerted action by the railway and union to protect their jobs to a lesser extent than the whites was satisfactory. ${ }^{30}$ The Court also held that a claimant is not required to "set out in detail the facts upon which he bases his claim" under the Federal Rules. ${ }^{31}$ The Court noted that if petitioners' allegations were proven, it would constitute a patent breach of the union's statutory obligation to represent employees fairly and without discrimination. ${ }^{32}$

Although Conley remained good law until Twombly's perceived rejection and Iqbal's reinforcement of a stricter standard, its pronounced standard was scrutinized by lower courts over the years. This scrutiny occurred predominately in the areas of antitrust; litigation over the Comprehensive Environmental Response, Compensation and Liability Act (CERCLA); civil rights; conspiracy; copyright; defamation; negligence; and the Racketeer Influenced and Corrupt Organizations Act (RICO). "Heightened pleading" is not a new concept. Federal Rule of Procedure 9(b) already imposes a heightened standard for alleging certain claims, stating, "In alleging fraud or mistake, a party must state

\footnotetext{
25. Spencer, supra note 6, at 435 .

26. Conley v. Gibson, 355 U.S. 41, 43 (1957), abrogated by Bell Atl. Corp. v. Twombly, 550 U.S. 544 (2007).

27. $I d$.

28. $I d$.

29. Id.

30. Id. at $45-46$.

31. Id. at 47 .

32. Id. at 46

33. See Fairman, supra note 22, at 1011-59 (analyzing a perceived wide range of factual detail required in federal complaints for the listed causes of action).
} 
with particularity the circumstances constituting fraud or mistake." ${ }^{34}$ In the Rule 8 realm, such a notion has long been perceived as applicable to particular areas of the law-namely, securities fraud and civil rights litigation. ${ }^{35}$ One of the most ardent attempts by lower courts to impose stricter standards concerned civil rights litigation during the Civil Rights Era. ${ }^{36}$ In a 1968 case, Valley v. Maule, a court plainly rejected Conley's standard as applied to civil rights cases, noting an increasing number of such claims and their imposition of "considerable expense, vexation and perhaps unfounded notoriety." ${ }^{37}$ Numerous circuit and district courts endorsed a heightened pleading requirement for civil rights actions after Valley and into the early nineties. ${ }^{38}$

These attempts caused the Supreme Court to address and strike down the imposition of heightened pleading in 1993, overruling lower courts' attempts to impose such a standard and reiterating Conley. That case was Leatherman $v$. Tarrant County Narcotics Intelligence \& Coordination Unit, where the Court reversed the Fifth Circuit, holding that the application of a heightened pleading standard in a civil rights action involving municipal liability does not exist. ${ }^{39}$ Nonetheless, some lower courts persisted in their application of a heightened standard, causing the Court to re-examine the issue almost a decade later in the employment discrimination arena. In Swierkiewicz v. Sorema N.A., the Court reversed the Second Circuit's dismissal of an employee's suit against a former employer that was based on the failure of the employee's complaint to adequately allege a prima facie case. ${ }^{40}$ Citing the language of Rule 8(a)(2) and Conley, the Court held that such a complaint need not establish a prima facie case. ${ }^{41}$ Importantly, the Swierkiewicz Court rejected respondent's argument that allowing lawsuits based on conclusory allegations would burden courts and encourage meritless claims, stating that "a requirement of greater specificity for particular claims is a result that 'must be obtained by the process of amending the Federal Rules, and not by judicial

34. FED. R. CIV. P. 9(b).

35. See Fairman, supra note 22, at 988; Richard L. Marcus, The Puzzling Persistence of Pleading Practice, 76 TEX. L. REV. 1749, 1750 (1998); A. Benjamin Spencer, Pleading Civil Rights Claims in the Post-Conley Era, 52 How. L.J. 99, 113 (2008).

36. See Spencer, supra note 35 , at 106-08.

37. Id. at 112 (quoting Valley v. Maule, 297 F. Supp. 958, 960-61 (D. Conn. 1968)).

38. Id. at $112-13$.

39. 507 U.S. 163, 168 (1993).

40. 534 U.S. 506, 515 (2002).

41. Id. at 514-15. 
interpretation." "42 These consistent affirmations of the Conley standard and refusal to judicially interpret Rule 8 (a) as requiring a heightened standard left litigants with a strong sense of where pleading stood in federal court.

\section{B. Twombly and Iqbal: Defining the New Heightened Standard}

The Supreme Court applied the "no set of facts" standard consistently until the Twombly decision in 2007. In Twombly, consumers brought a putative class action lawsuit against Incumbent Local Exchange Carriers (ILECs) alleging an antitrust conspiracy, in violation of the Sherman Act, to prevent competitive entry into local telephone and Internet service markets and to avoid competing with one another in their respective markets. ${ }^{43}$ The class alleged that the ILECs were engaged in illegal, anti-competitive parallel conduct. ${ }^{44}$ The Court held that in a Section 1 Sherman Act allegation, the "claim requires a complaint with enough factual matter (taken as true) to suggest an agreement was made." ${ }^{45}$ No such factual matter was pled, the Court held, because a mere statement of parallel conduct, even if consciously taken, "needs some setting suggesting the agreement necessary to make out a [section] 1 claim." 46 Most importantly, the Court announced a standard that only required "enough facts to state a claim to relief that is plausible on its face." 47 The Court did away with the "no set of facts" language from Conley, stating that the "phrase is best forgotten as an incomplete, negative gloss on an accepted pleading standard: once a claim has been stated adequately, it may be supported by showing any set of facts consistent with the allegations of the complaint." ${ }^{48}$

Important language was used to describe what allegations will not stand-“a plaintiff's obligation to provide the 'grounds' of his 'entitle[ment] to relief' requires more than labels and conclusions, and a formulaic recitation of the elements of a cause of action will not do." ${ }^{, 9}$ The Court indicated the lower limits of the standard by stating that a complaint may proceed even if it strikes the "judge that actual proof of

\footnotetext{
42. Id. (quoting Leatherman, 507 U.S. at 168) (emphasis added).

43. Bell Atl. Corp. v. Twombly, 550 U.S. 544, 550-51 (2007).

44. Id. at 550 .

45. Id. at 556

46. Id. at 557 .

47. $I d$. at 570 .

48. Id. at 563 .

49. Id. at 555 .
} 
those facts is improbable, and 'that a recovery is very remote and unlikely." "50 The oft-cited language that subsequent cases gleaned from Twombly was that plaintiffs must plead enough facts to state a claim for relief that "nudge[s] their claims across the line from conceivable to plausible." 51

Notable in Justice Stevens's dissent was his criticism that the Court underestimated a trial court's case management capabilities. ${ }^{52}$ He cited Federal Rule 26 as granting courts broad discretion in controlling discovery, including the "sequence in which such discovery devices may be deployed; and the limitations imposed on them." 53 He argued such discretion could be employed in considering the plaintiffs' proposed "phased discovery" for issues of the alleged conspiracy and class certification. ${ }^{54}$

The Twombly decision generated much discussion about the parameters of its application. Iqbal greatly reduced this speculation. In Ashcroft v. Iqbal, plaintiff Javaid Iqbal, a Muslim Pakistani, was arrested on criminal charges and detained by federal officials on suspected links to terrorist activity after the September 11, 2001 terrorist attacks. ${ }^{55}$ Iqbal's complaint alleged numerous causes of action, several of which revolved around his treatment while in a special maximum security prison in Brooklyn, New York. ${ }^{56}$ However, the allegations pertinent in Iqbal's Supreme Court case were that former Attorney General John Ashcroft and Director of the Federal Bureau of Investigation Robert Mueller violated his First and Fifth Amendment rights under the Constitution by designating him as a person of high interest because of his race, religion, or national origin. ${ }^{57}$ Iqbal also alleged that both Ashcroft and Mueller "knew of, condoned, and willfully and maliciously agreed to subject" him to the confinement conditions he endured. ${ }^{58}$ Iqbal alleged Ashcroft was the "principal architect" of the policy that designated him a high interest individual and that Mueller was "instrumental in [its] adoption, promulgation, and implementation.",59

50. Id. at 556 (quoting Schener v. Rhodes, 416 U.S. 232, 236 (1974)).

51. Id. at 570; see also Ashcroft v. Iqbal, 129 S. Ct. 1937, 1951 (2009) (applying this language from Twombly)

52. Twombly, 550 U.S. at 594 n.13 (Stevens, J., dissenting).

53. Id.

54. Id.

55. Iqbal, 129 S. Ct. at 1942.

56. Id. at 1943-44.

57. Id.

58. Id. at 1944.

59. Id. 
Iqbal applied the new "heightened" standard in Twombly by painting with a broad brush. Writing for a five-to-four majority, Justice Kennedy discounted the distinction between the Court's interpretation of Rule 8 in Twombly's antitrust context and the civil rights situation in Iqbalnoting the transsubstantive nature of the Federal Rules. ${ }^{60} \mathrm{He}$ asserted that Rule 8 "governs the pleading standard 'in all civil actions and proceedings in the United States district courts.' Our decision in Twombly expounded the pleading standard for 'all civil actions,' and it applies to antitrust and discrimination suits alike." ${ }^{\prime 61}$ The Court then elucidated a two-pronged approach to test the sufficiency of a Rule 12(b)(6) challenge to a complaint. ${ }^{62}$

The first step is to distinguish between legal conclusions and factual allegations to identify pleadings that "are not entitled to the assumption of truth." ${ }^{63}$ Second, the court should determine whether the factual allegations are well-pleaded so as to support the legal conclusions; if such allegations are found, the court is to "assume their veracity and determine whether they plausibly give rise to an entitlement to relief." 64 The Court applied this two-prong test to hold that Iqbal's complaint failed to include facts that plausibly showed Ashcroft and Mueller intentionally adopted a policy of classifying detainees like Iqbal as "high interest" because of their race, religion, or national origin. ${ }^{65}$

Notably, Justice Souter, author of the Court's opinion in Twombly, wrote the dissent in Iqbal, arguing that the majority misapplied the pleading standard set forth in Twombly. ${ }^{66}$ Justice Souter's critique was a technical one, claiming that the majority incorrectly examined the complaint's contested allegations in isolation. ${ }^{67} \mathrm{He}$ accused the majority of selecting certain conclusory statements and squaring them with its treatment of other allegations as nonconclusory. ${ }^{68}$

Like Twombly, Iqbal also discussed discovery and case management issues. Many were addressed in the Second Circuit's opinion, which held that, in a qualified immunity case, the district court may "consider exercising its discretion to permit some limited and tightly controlled reciprocal discovery so that a defendant may probe for amplification of a

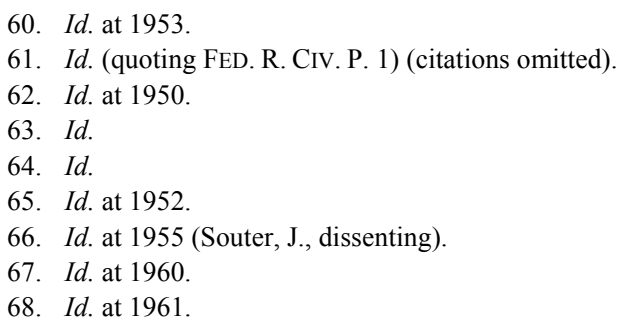


plaintiff's claims and a plaintiff may probe such matters as a defendant's knowledge of relevant facts and personal involvement in challenged conduct." 69 Additionally, the Second Circuit noted that

a district court might wish to structure such limited discovery by examining written responses to interrogatories and requests to admit before authorizing depositions, and by deferring discovery directed to high-level officials until discovery of front-line officials has been completed and has demonstrated the need for discovery higher up the ranks. 70

However, the Supreme Court's majority opinion in Iqbal reversed, noting that the trial judge's option to exercise careful case management that allows for carefully targeted discovery is unwarranted. ${ }^{71}$ The Court's reasoning was based on Twombly's holding that on motions to dismiss, the question "does not turn on the controls placed upon the discovery process." 72 The Court gave special deference to the fact that the Iqbal defendants, petitioners Ashcroft and Mueller, are entitled to qualified immunity, because the purpose of that defense is to "free officials from the concerns of litigation, including 'avoidance of disruptive discovery." ${ }^{\prime 73}$ Justice Breyer's dissent in Iqbal focused almost exclusively on the issue of discovery. ${ }^{74} \mathrm{He}$ agreed with the Second Circuit and stated that in a qualified immunity case, "a district court, for example, can begin discovery with lower level government defendants before determining whether a case can be made to allow discovery related to higher government officials." 75

Twombly and Iqbal differed on the causes of action adjudicated and the type of plaintiff. One may also note the differing political undertones of the cases. Iqbal dealt with a 9/11-era policy advanced by the Bush Administration, a more politicized issue than Twombly's class action antitrust scenario. This skepticism aside, the shifting dichotomy of the Court, from Twombly's seven-to-two decision to Iqbal's five-to-four decision, likely reflects some of the Justices' unwillingness to extend what had been perceived as a heightened standard to all civil actions. In some sense, Twombly's antitrust context provided the necessary scenario

69. Iqbal v. Hasty, 490 F.3d 143, 158 (2d Cir. 2007), rev'd sub nom. Ashcroft v. Iqbal, 129 S. Ct. 1937 (2009).

70. Id.

71. Iqbal, 129 S. Ct. at 1953.

72. Id.

73. Id. (quoting Siegert v. Gilley, 500 U.S. 226, 236 (1991)).

74. Id. at 1961-62 (Breyer, J., dissenting).

75. Id. 
for the Court to articulate a more modern pleading standard that lower courts had been striving toward in the decades prior. ${ }^{76}$ Yet, the standard's extension to all civil actions was likely not envisioned by some members of the Court at the time of Twombly.

\section{Responses to the New Standard}

Both the Twombly and Iqbal opinions have been heavily cited. ${ }^{77}$ This suggests two things: (1) litigants, chiefly defendants, have noted the new weapon provided to them; and (2) courts have, in part, endorsed this weapon's usage, possibly because of the desire to exercise judicial efficiency and docket control. The result of both cases has been to grant more discretion to the judiciary and leave litigants with an indistinct impression of where pleading stands today. The Notice Pleading Restoration Act of $2009^{78}$ and Access to Open Courts Act of $2009^{79}$ are legislative efforts substantiating a general concern that the new standard will deprive individuals of a fair attempt at justice. In a House Judiciary Committee Meeting on October 27, 2009 entitled "Access to Justice Denied-Ashcroft v. Iqbal," several witnesses asserted that the pleading standard was too high. ${ }^{80}$ One, in particular, went so far as to say, "A person is now barred from entering the courthouse absent being able to drum up facts that convince a federal judge-someone who breathes fairly rarified air - that her claim is subjectively plausible." 81 Such a claim is in tune with much of the criticism of modern pleading after Iqbal.

76. See Bone, supra note 24, at 884 (noting that Twombly was appropriate for dismissal on the pleadings because of its features associated with nonmeritorious filings and high discovery costs, and the fact that the allegations really did not indicate that the claim had merits).

77. See, e.g., Alison Frankel, Mr. Iqbal Goes to Washington, AmLaW Litig. Daily, Oct. 28 , 2009, available at $\mathrm{http}: / /$ www.law.com/jsp/tal/digestTAL.jsp?id=1202435006595\&Mr_Iqbal_Goes to Washington (noting that as of October 28, 2009, Iqbal had already been cited more than 3,000 times in lower court rulings); Bone, supra note 24, at 877 (noting that Twombly was cited 4000 times the first nine months after it was decided).

78. S. 1504, 111th Cong. (2009).

79. H.R. 4115, 111th Cong. (2009).

80. See Frankel, supra note 77. These witnesses included Arthur Miller of the New York University School of Law, John Vail of the Center for Constitutional Law, and Debo Adegbile of the NAACP Legal Defense and Education Fund.

81. See id. (quoting John Vail of the Center for Constitutional Law). 


\section{ANALYSIS}

\section{A. Perceived and Actual Ramifications of Twombly and Iqbal}

Iqbal's application of Twombly's plausibility standard in a civil rights context, indeed, in all civil actions, has caused concern among many. ${ }^{82}$ The importance of defeating a defendant's motion to dismiss is obvious - accessing justice and having one's rights vindicated-yet, these cases have raised the stakes at this early stage in litigation. One main criticism of the Iqbal standard is that it is not consistent with the liberal principles behind notice pleading. ${ }^{83}$ The new standard arguably prohibits plaintiffs from bringing actions based on facts they could not reasonably be expected to ascertain. ${ }^{84}$ By rejecting Conley's "no set of facts" standard, Twombly and Iqbal effectively made a trade-off-justice for efficiency. Even if Iqbal was correctly decided on the facts, there is a danger in sustaining motions to dismiss under a plausibility standard when plaintiffs' allegations stem from organizational mistreatment and the accused are too far-removed to garner the requisite factual enhancement. Iqbal has affected cases in federal court and is likely to impact cases filed in state courts as well because rules of procedure at the state level are typically patterned on the Federal Rules. ${ }^{85}$

Scholars have criticized the standard for its lack of clarity and precision, leaving the judiciary and litigants without a plain understanding of its meaning. ${ }^{86}$ Some courts interpret current pleading doctrine as plainly mandating heightened pleadings, while others note a tension between the latter and notice pleading, and still others continue to endorse the traditional liberal standard. ${ }^{87}$ The plausibility standard's goal of preventing unworthy discovery and case-management costs, as stated in Twombly, is misplaced when the standard is so unclear as to keep

82. See Robert G. Bone, Plausibility Pleading Revisited and Revised: A Comment on Ashcroft v. Iqbal, 3 (Boston Univ. Sch. of Law Working Paper No. 09-41 Sept. 3, 2009) (noting that after Iqbal, many critics now believe that it is imperative to understand the effects of plausibility pleading); Peter Vieth, Federal Pleading Standard Promotes Removal, VA. LAW. WKLY., Aug. 31, 2009 (quoting a lawyer deeming Iqbal "troubling").

83. See Spencer, supra note 6, at 431-32.

84. See, e.g., Ashcroft v. Iqbal, 129 S. Ct. 1937 (2009) (concerning plaintiff, Javaid Iqbal, who could not have possibly had information about the impropriety of Attorney General Ashcroft and other high-level government officials).

85. Lonny Hoffman, Using Presuit Discovery to Overcome Barriers to the Courthouse, 34 LiTiG. 31, 32 (2008).

86. See, e.g., Spencer, supra note 2, at 1.

87. See id. at 7-8 (discussing the varied interpretations of courts applying the Twombly standard). 
litigants in a state of speculation. Additionally, Iqbal has been criticized for extending the defeat of suits that are actually meritless, like Twombly, to suits that are merely weak. ${ }^{88}$

One procedural implication of Twombly's application to all civil actions stems from the difference between state and federal pleading standards. ${ }^{89}$ Where possible, defendants may be more likely to seek removal in favor of the higher standard placed on complaints in federal court.

1. Inability of "Far-Removed" Plaintiffs to Substantiate Factual Matters

As a preliminary matter, Iqbal has had an effect on claimants bringing lawsuits of every nature. In particular, the ability of litigants like Javaid Iqbal to successfully allege impropriety is difficult because of their inability to access crucial factual material absent some kind of discovery. In the face of the higher standard, the pleas of these claimants will be dead on arrival. Essentially, Iqbal can be viewed as denying potentially valid claims that do not yet have the requisite facts. The Court's reluctance to endorse "phased" discovery in Twombly illustrates the uphill battle that claimants face. In the antitrust context, the Court made clear that only through ensuring that a complaint's allegations reach a suggestive level will enormous discovery expenses be avoided. $^{91}$

Thus, surviving a motion to dismiss can prove impossible for plaintiffs who face the need to allege specific evil motives or wrongdoings of high-level officials. ${ }^{92}$ Even though civil rights and other similar claims are often in the context of large organizationsgovernmental, industrial, or otherwise - that involve complex claims against multiple defendants, they are still required to plead sufficient factual material to suggest their claim. These cases also have a tendency

88. See generally Bone, supra note 82 (discussing implications of screening weak lawsuits versus meritless ones).

89. See FrIEDENTHAL ET AL., supra note 20, at 512 (noting that the Federal Rules have a "strong impact" on most states' civil procedure rules but that some "still vary greatly").

90. See Bell Atl. Corp. v. Twombly, 550 U.S. 544, 559-60 n.6 (2007) (elaborating on the majority's perceived limitations of "phased" discovery).

91. See id. at 559 ("[I]t is only by taking care to require allegations that reach the level of suggesting conspiracy that we can hope to avoid the potentially enormous expense of discovery ....").

92. See Stephen B. Burbank, Pleading and the Dilemmas of "General Rules", 2009 WIS. L. REV. 535, 561 (2009) (noting that Twombly will deny court access to people that have meritorious claims "either because they lack the resources to engage in extensive prefiling investigation or because of informational asymmetries"). 
to reflect larger policy matters that courts may be reluctant to accept or manage in the first place.

\section{Incentivized Removal to Federal Court}

Another implication of Iqbal is the increased attractiveness of a federal forum to defendants because of the higher pleading standard. State courts are divided in their endorsement of the Twombly pleading standard. Prior to Twombly, twenty-six states and the District of Columbia modeled their dismissal standards on Conley. ${ }^{93}$ South Dakota is one state that seemingly abandoned its notice-based pleading regime in favor of Twombly's standard in Sisney v. Best. ${ }^{94}$ That court's reasoning was essentially that because South Dakota's statute mirrored the Federal Rules by requiring a "showing' that the pleader is 'entitled' to relief," it seemed appropriate to embrace Twombly. ${ }^{95}$ Yet, two months later, the same court awkwardly clarified that in spite of their adoption of Twombly and overruling of prior cases relying on Conley, South Dakota still embraced notice pleading. ${ }^{96}$

Other states that have confronted the standard have eschewed it in favor of their existing notice pleading regime. For example, Arizona firmly stated that in spite of Twombly it remains loyal to its interpretation of its own statute, which mirrors Federal Rule 8(a), but has been interpreted differently than both Conley and Twombly. ${ }^{97}$ Vermont also faced an argument for the application of the heightened standard: because the state had adopted its standard based on Conley, it should now follow Twombly. ${ }^{98}$ The Vermont Supreme Court dismissed the argument and reiterated its judicial independence stating, "[W]e ... are in no way bound by federal jurisprudence in interpreting our state pleading rules." 99

In spite of these disinclinations, states, like the aforementioned, that did not alter their standards post-Twombly to align with the Twombly standard may be more likely to do so after Iqbal. This is because Iqbal clearly rejects the notion that the plausibility standard is limited to antitrust cases and provides more procedural clarity and uniformity.

93. Twombly, 550 U.S. at 578 (Stevens, J., dissenting); Dodson, supra note 12, at 141.

94. Sisney v. Best Inc., 754 N.W.2d 804, 808-09 (S.D. 2008).

95. Id.

96. Gruhlke v. Sioux Empire Fed. Credit Union, 756 N.W.2d 399, 409 (S.D. 2008).

97. Cullen v. Auto-Owners Ins. Co., 189 P.3d 344, 346-48 (Ariz. 2008).

98. Colby v. Umbrella, Inc., 955 A.2d 1082, 1086 n.1 (Vt. 2008).

99. Id. 
State courts may find the uniform application to all civil cases an attractive policy for judicial economy reasons. Conversely, states, like Arizona and Vermont, may maintain that their pleading regime is superior and demonstrate reluctance to federal influence. Various federal courts also differ in their treatment of applying the standard to affirmative defenses, which will be examined.

Insofar as state courts retain a more liberal notion of pleading that rests on Conley's "no set of facts" standard or something similar, federal courts will be the likely choice of forum for defendants. One commentator has suggested that such preferences will likely come to fruition, and even detailed a specific instance of one such partiality. ${ }^{100}$ Scholars have called forum selection "the name of the game" for lawyers and removal can be a key phase in executing that selection. ${ }^{101}$ Although, there will be limitations to removal, markedly the ability to establish that the amount in controversy exceeds $\$ 75,000$ and that the parties are diverse or that there is a federal question disputed. ${ }^{102}$ Interestingly, if the pleading dichotomy between state and federal courts actually creates this preference, it is likely that one of Twombly's stated purposes - to reduce litigation costs-will be refuted. Incentivizing removal will only result in more transactional costs to the litigant by way of more billable hours spent on pleading and peripheral costs like travel to the federal venue.

\section{Applying "Plausibility" to Affirmative Defenses}

The focus on pleading after Twombly and Iqbal centered on the complaint because both cases adjudicated a Rule 12(b)(6) motion, but courts have since addressed another implication of those decisionswhat standard to apply to defenses pled. While a minority of courts have not applied the heightened Twombly-Iqbal standard to affirmative defenses, the majority view endorses applying the standard to these pleadings. ${ }^{103}$ This is necessary because, as one court noted, "otherwise a court could not make a Rule 12(f) determination on whether an affirmative defense is adequately pleaded under Rules 8 and/or 9 and

100. Vieth, supra note 82 (alluding to a Virginia court's ruling in Branham v. Dolgencorp Inc.).

101. See Kevin M. Clermont, Litigation Realities Redux, 84 Notre DAME L. ReV. 1919, 192122 (2009)

102. See 28 U.S.C. $\S \S 1331-1332$ (2006).

103. Hayne v. Green Ford Sales, Inc., No. 09-2202-JWL-GLR, 2009 WL 5171779, at *2 (D. Kan. Dec. 22, 2009). 
could not determine whether the affirmative defense would withstand a Rule 12(b)(6) challenge." 104

The minority view is based on the rationale that because Twombly was interpreting Rule 8(a) and not Rule 8(b), relating to defenses generally, or Rule $8(\mathrm{c})$, relating to affirmative defenses, the heightened standard should not apply to them. ${ }^{105}$ The majority approach is more logical considering the balance needed between pleading parties. To apply the standard to one party and not the other ignores the purpose of both pleadings - to provide notice to the other party that some plausible basis for the assertion exists. Similar to Rule 8(a)(2), Rule 8(b)(1)(A) requires the litigant to "state in short and plain terms [the party's] defenses to each claim asserted against it."106 This similarity, coupled with the general application of Rule $8(\mathrm{~b})$ to defenses, indicates that affirmative defenses should be judged by the same standard.

\section{Disadvantages of Current Doctrine and the Need for Pleading} Reform

The primary disadvantages of current pleading doctrine are the inconsistency with which it is applied, its general lack of clarity, and its divergence from traditional liberal notice pleading. The inconsistency leaves litigants guessing how the judiciary will construe "plausibility" as to the allegations of their complaint. This causes an "unpredictability that will underdeter frivolous claims and overencourage motions to dismiss." 107 The traditional principle that courts are to accept all factual allegations as true has been tainted by Twombly and Iqbal, which have caused courts to be more skeptical in their determination of whether facts are plausible. ${ }^{108}$

When a judge exercises her discretion in construing "plausibility," she provides a more comprehensible view of her notion of that term as applied to certain facts. In doing so, it may lead to increased forum shopping by defendants. Such a preference may be particularly likely because of the complex and high stakes nature of the cases in which the

104. United States v. Quadrini, No. 2:07-CV-13227, 2007 WL 4303213, at *4 (E.D. Mich. Dec. 6, 2007).

105. See generally First Nat'1 Ins. Co. v. Camps Servs., Ltd., No. 08-cv-12805, 2009 WL 22861 (E.D. Mich. Jan. 5, 2009); Romantine v. CH2M Hill Eng'rs, Inc., No. 09-973, 2009 WL 3417469 (W.D. Pa. Oct. 23, 2009).

106. FED. R. CIV. P. 8(b)(1)(A).

107. Spencer, supra note 2 , at 1 .

108. Id. at 8-9. 
current pleading standard is likely to be contested, like class actions. Defendants may be allowed considerable choice of venue in those circumstances. Again, such a practice results in increased litigation costs by way of research, pleadings, and travel, counter to the emphasis on judicial economy in Twombly. ${ }^{109}$

Pleading doctrine, like many legal doctrines, has always suffered from lack of clarity on some level. Inherent in legal argument is construing words to be most favorable to one's client. However, current plausibility doctrine adds something to the traditional lack of clarity that was centered on Conley's language and the word "showing" in Rule $8(a)(2)$; the addition of "conceivable to plausible" and related phrases leaves litigants wondering where exactly their claims fall. ${ }^{110}$

Another disadvantage is the extent to which it conflicts with the traditional doctrine of notice pleading. Twombly's emphasis on providing factual allegations showing the claimant is entitled to relief has been criticized as being counter to the understanding of the drafters of the Federal Rules. ${ }^{111}$ There has even been speculation that the standard is at odds with Form 11 of the Federal Rules of Civil Procedure. ${ }^{112}$ Form 11 does not require plaintiffs to plead facts that establish a defendant's negligence. Professor A. Benjamin Spencer, a respected scholar on the current state of pleading, uses the fundamental example of a negligence claim arising from a car wreck. Facts pled surrounding the defendant's negligence - such as use of a cell phone while driving or speeding - are not necessary to state a claim. This is because the surrounding fact of a collision creates a presumption of impropriety that gives the plaintiff the right to proceed to discovery where he has a good chance of substantiating his allegation of impropriety. ${ }^{113}$ He further reasons that Form 11 does not require plaintiffs to allege such facts as cell phone use or speeding because they "may not be able to know [these facts] prior to discovery." 114 However, under the current standard, if the plaintiff was

109. See Bell Atl. Corp. v. Twombly, 550 U.S. 544, 559 (2007).

110. Spencer, supra note 2, at 11; see also Iqbal v. Hasty, 490 F.3d 143, 178 (2007) (Cabranes, J., concurring) (noting that Bell Atlantic and relevant Second Circuit precedents are "less than crystal clear and fully deserve reconsideration by the Supreme Court at the earliest opportunity; to say the least, "the guidance they provide is not readily harmonized"'), rev'd sub nom., Ashcroft v. Iqbal, 129 S. Ct. 1937 (2009).

111. Spencer, supra note 6 , at 442 .

112. Spencer, supra note 2, at 13; see also Doe ex. rel. Gonzales v. Butte Valley Unified Sch. Dist., No. Civ. 09-245, 2009 WL 2424608, at *8 (E.D. Cal. Aug. 6, 2009) (noting that "even the official Federal Rules of Civil Procedure Forms . . . have been cast into doubt by Iqbal").

113. Spencer, supra note 2, at 27-28.

114. Id. 
hit from behind and had no information about the tortfeasor's contribution to the accident, his claim would fail. ${ }^{115}$

A clearer standard would provide more reliability for litigants pursuing their cases. They will not find themselves speculating about what a particular judge's idea of "plausibility" is and will have a better idea of the merits of their claim. Cases perceived to have a weak merits basis would not be excluded based on their lack of factual pleading. To be sure, a reversion to Conley may be unwarranted, but something clearer than the current standard is warranted.

\section{B. Judicial Remedies}

Having established the problems with the current pleading doctrine, the issue then becomes a suitable and effective remedy. A few exist in the judicial arena, but would require judicial activism that judges are unlikely to exercise short of a more unambiguous standard from the Supreme Court. However, the next section will further illustrate the types of issues that formal rulemaking - amending the Federal Rules or enacting claim-specific laws ${ }^{116}$ — can help clarify.

\section{Discretion in Defining "Plausibility"}

The language of the plausibility standard provides courts discretion in determining whether a complaint states a plausible claim for relief by noting that it will require courts to engage in a "context-specific task that requires the reviewing court to draw on its judicial experience and common sense." 117 Similarly, Justice Souter's dissent in Iqbal reiterated his statement in Twombly that "a court must take the allegations as true, no matter how skeptical the court may be," adding his exception for sufficiently fantastic allegations concerning little green men or time travel experiences. ${ }^{118}$ Such a statement illustrates the level of scrutiny the author of Twombly envisioned applying to factual allegations in a complaint — one that the Iqbal majority refuted and heightened. As evident from the majority and dissent in Iqbal, judges have differing notions of plausibility. Other factors also play into a court's plausibility determination, like the errors alleged by the Iqbal dissent, namely, that

115. Id.

116. See discussion infra Parts III.C-D.

117. Ashcroft v. Iqbal, 129 S. Ct. 1937, 1950 (2009).

118. Id. at 1959 (Souter, J., dissenting). 
the majority isolated contested allegations and failed to read them in conjunction with other paragraphs of the complaint. ${ }^{119}$

Lower courts' decisions after Twombly and Iqbal also serve as evidence of such variation. ${ }^{120}$ The term itself gives courts significant flexibility in determining whether a plaintiff is entitled to relief and is a significant reason for the lack of clarity under current doctrine. One scholar captures the need for courts to provide a clearer definition:

Concepts such as "more than labels and conclusions," "above the speculative level," "plausible grounds to infer," "enough factual material to suggest," "reasonable expectation," and "enough heft" are instructive in that they tell litigants that more than a possibility but less than a probability must be shown. Beyond that, however, there is uncertainty regarding precisely what level of factual detail will make a statement of a claim plausible and nonspeculative. Indeed, courts may disagree regarding the plausibility of a claim unless that term is given more objective definition. ${ }^{121}$

The likelihood of courts uniting behind a clearer standard is not great considering the discretion that the plausibility standard allows. ${ }^{122}$ The surge in applying the plausibility standard, even to cases outside of a "complex" context after Twombly, ${ }^{123}$ suggests that some courts endorse such a standard, but nevertheless, still face the standard's lack of precision. Following Iqbal, one federal district court interpreted the Court's plausibility standard as a "highly contextual enterprisedependent on the particular claims asserted, their elements, and the overall factual picture alleged in the complaint." ${ }^{\text {2124 }}$ While the obligation to follow precedent may seemingly tip the scale toward a clearer standard, the previous quote illustrates the latitude given judges in defining plausibility. The usual application of the standard would still be in favor of heightened pleading to the detriment of plaintiffs, especially in certain contexts. Because of the direction civil litigation is headed and the binding precedents of Twombly and Iqbal, it is unlikely that such

119. Id. at $1960-61$.

120. See Spencer, supra note 2, at 7-8.

121. Id. at 11 .

122. See Nicholas Tymoczko, Note, Between the Possible and the Probable: Defining the Plausibility Standard after Bell Atlantic Corp. v. Twombly and Ashcroft v. Iqbal, 94 MinN. L. Rev. 505,518 (2009) (noting that "the actual meaning of the plausibility standard... remains as important and as unclear as ever").

123. See Spencer, supra note 6, at 458 (noting the application of Twombly to all cases by lower federal courts).

124. Chao v. Ballista, 630 F. Supp. 2d 170, 177 (D. Mass. 2009). 
judicial discretion would remedy the more fundamental problem of the standard's application to all civil actions.

\section{Allowance of Minimally Intrusive "Phased" Discovery}

Modern complex litigation and the exorbitant discovery costs it can impose have been serious judicial considerations in defining heightened pleading standards for certain claims. In Twombly itself, the court expressed concern that "sprawling, costly, and hugely timeconsuming" 125 discovery would "push cost-conscious defendants to settle even anemic cases." 126 The Court cited one study showing that discovery can account for up to ninety percent of litigation costs if actively employed. $^{127}$ However, several commentators have challenged the Court's emphasis on discovery costs as a justification for imposing a higher standard. ${ }^{128}$

Modifying pleading standards has an unavoidable effect on discovery and other pretrial procedures. ${ }^{129}$ Because notice pleading rests on the idea that further investigation will flesh out the facts behind the claim, the broad means of discovery should obviate the need for parties to state facts in detail at the pleading stage. ${ }^{130}$ With notice pleading eschewed in favor of a higher standard, it would seem appropriate that discovery be altered in some way as well. However, as detailed in Part II.B, the Iqbal Court rejected the Second Circuit's views on one possible remedy_-"phased" discovery_noting that "the success of judicial supervision in checking discovery abuse has been on the modest side.""131 The Court also gave substantial weight to the fact that the defendants had qualified immunity as government officials and was reluctant to burden the execution of their duties with discovery. ${ }^{132}$

In a sense, Iqbal's reliance on Twombly's discovery reasoning is warranted because both cases involved the extreme ends of

\footnotetext{
125. Bell Atl. Corp. v. Twombly, 550 U.S. 544, 559 n.6 (2007).

126. Id. at 559 .

127. Id.

128. See, e.g., Marcus, supra note 35, at 1769 (noting that plaintiffs sometimes set forth more detailed pleadings, even if not required to do so, depending on their evaluation of certain factors, one of which is the potential cost of discovery); Spencer, supra note 2, at 35-36 (arguing that the cost of discovery does not affect whether plaintiffs satisfy the plausibility threshold in their pleadings).

129. Z.W. Julius Chen, Note, Following the Leader: Twombly, Pleading Standards, and Procedural Uniformity, 108 CoLUM. L. REV. 1431, 1453 (2008).

130. FRIEDENTHAL ET AL., supra note 20, at 513.

131. Ashcroft v. Iqbal, 129 S. Ct. 1937, 1953 (2009) (quoting Bell Atl. Corp. v. Twombly, 550 U.S. $544,559(2007))$.

132. Id.
} 
organizational hierarchy and multiple defendants that could produce sprawling and exorbitant discovery costs. Yet, Iqbal's application to all civil actions decreases the relevance of a pervasive rejection of "phased discovery." Many instances of actionable discrimination, for example, occur in the context of mid-sized corporations, educational institutions, government agencies, or other organizations for which discovery would pose no such burden. Justifying heightened pleading based on costly discovery or burden alone is not a sufficient reason to deny plaintiffs access to courts.

Federal Rule 27, as stated and interpreted by courts, recognizes a narrow allowance for presuit discovery. Iqbal's rejection of a careful case management approach seemed to be specific to the Second Circuit's instructions to the district court and did not necessarily implicate this rule. ${ }^{133}$ The pertinent part of the rule states that "to perpetuate testimony about any matter cognizable in a United States court," an oral or written deposition may be taken to "prevent a failure or delay of justice." "134 However, courts almost uniformly construe Rule 27 as applicable in three contexts: (1) to preserve witness testimony when there is a credible risk that the testimony may be lost if not recorded immediately; (2) to confirm the proper party to name as a defendant or to gather additional information necessary to institute legal proceedings; and (3) to investigate presuit claims. ${ }^{135}$ The best opportunity for presuit discovery to combat heightened pleading standards falls in the last context. However, few courts have allowed plaintiffs under Rule 27 to investigate potential claims or confirm the proper defendant to sue. ${ }^{136}$ Therefore, it may be unlikely for a court, without precedent or a more explicit rule, to allow litigants to use presuit discovery to substantiate potentially meritless allegations.

Variation in states' versions of Rule 27 may also contribute to more active forum selection. ${ }^{137}$ For example, New York's version of the rule allows claimants to gather more information necessary for commencing a legal proceeding. ${ }^{138}$ Some other states authorize a much more extensive use of presuit discovery. Texas allows forthcoming plaintiffs to perpetuate testimony "for use in anticipated suit" or "to investigate a

\footnotetext{
133. See id.

134. FED. R. CIV. P. 27(a)(1), (3).

135. See id.

136. Hoffman, supra note 85 , at 33 .

137. See forum-selection discussion supra Part III.A.2

138. Hoffman, supra note 85, at 33. However, most New York courts only allow such use of the rule to add to factual claims already known to exist. $I d$.
} 
potential claim or suit."139 The size of these two states is not without significance in analyzing their rules' effects on forum selection, particularly in the products liability and antitrust class action arena. More businesses are likely to have their principal place of business there and be subjected to suit in those jurisdictions. Both plaintiffs and defendants might be more inclined to seek these venues, insofar as plaintiffs believe their claims to be meritorious or defendants believe plaintiffs' claims to be without merit.

\section{Increased Enforcement of Rule 11 to Combat Meritless Claims and} Discovery Abuses

Rule 11 is another judicial mechanism that could be employed to combat the frivolous and bothersome claims that were a partial reason for the Court raising the standard. Dissenting in Twombly, Justice Stevens articulated the relevance to and availability of Rule 11 against meritless claims, stating "should it become apparent over the course of litigation that a plaintiff's filings bespeak an in terrorem suit, the district court has at its call its own in terrorem device, in the form of a wide array of Rule 11 sanctions." ${ }^{140}$ The rule makes clear that by an attorney "presenting to the court a pleading, written motion, or other paper ... an attorney certifies that to the best of the person's knowledge, information, and belief, formed after an inquiry reasonable under the circumstances," the presentation is not being made to cause unnecessary delay, is not frivolous, and will have evidentiary support after a reasonable investigation. ${ }^{141}$ Rule 11 also provides the court with the ability to sanction an attorney if his or her actions are found in violation of subsection (b). ${ }^{142}$

One drawback of increasing Rule 11's use against meritless claims in the post-Iqbal era is that it would place too much pressure on attorneys to conduct a plausibility analysis from the outset. Given the difficulty and inconsistency courts themselves have had with such an analysis, the desire for claimants to have their rights vindicated should not hinge on attorneys fearing plausibility. Additionally, an attorney may never have the opportunity for "reasonable investigation" when the courts have seemingly closed the door on "phased discovery" that allows litigants to gain the now-requisite factual assertions.

139. Id

140. Bell Atl. Corp. v. Twombly, 550 U.S. 544, 595 n.13 (2007) (Stevens, J., dissenting).

141. FED. R. CIV. P. 11(b).

142. FED. R. CIV. P. 11(c). 
Rule 11 was amended in 1993 to combat a perceived "chilling effect" that was making lawyers less likely to file meritorious claims in court and disproportionately affected plaintiffs' lawyers and lawyers asserting pro bono causes. ${ }^{143}$ These amendments, among other things, granted courts more discretion in imposing sanctions, expressly supported non-monetary sanctions, and provided that opposing parties must be served with Rule 11 motions twenty-one days prior to filing them with the court. ${ }^{144}$ The intent of these amendments may make courts less likely to impose sanctions on plaintiffs to weed out frivolous claims rather than applying a heightened standard. Indeed, Rule 11 sanctions have been reduced in recent years and the trend is likely to continue. ${ }^{145}$

\section{Amending the Federal Rules}

In rulings prior to Twombly concerning Rule 8(a)(2), the Supreme Court acknowledged that certain claims might be subjected to a heightened requirement if "Rules 8 and 9 were rewritten today," adding that such a ruling would have been attained by the "process of amending the Federal Rules." 146 Similarly, in Crawford-El v. Britton, the Court responded to the appellate court's rationale of imposing a heightened standard to reduce the access to discovery in actions that require proof of motive. ${ }^{147}$ It noted that issues concerning pleading, discovery, and summary judgment are "most frequently and most effectively resolved either by the rulemaking process or the legislative process."148 Obviously, these acknowledgements are noteworthy, given the Supreme Court's actions in both Twombly and, to a greater extent, Iqbal. Even in Twombly, the Court stated that they were not applying a heightened standard and that doing so would require an amendment of the Federal Rules, not judicial interpretation. ${ }^{149}$ The more even split of the Court in Iqbal than in Twombly likely reflects the Court's previously stated

143. Danielle Kie Hart, And the Chill Goes On-Federal Civil Rights Plaintiffs Beware: Rule 11 Vis-à-vis 28 U.S.C. $\$ 1927$ and the Court's Inherent Power, 37 LoY. L.A. L. REV. 645, 656-57 (2004).

144. Id. at 658

145. Id. at $646-47$.

146. Leatherman v. Tarrant County Narcotics Intelligence and Coordination Unit, 507 U.S. 163, 168 (1993) (declining to apply a heightened standard in a $§ 1983$ claim against a municipality); see also Swierkiewicz v. Sorema N.A., 534 U.S. 506, 515 (2002) (stating that the Federal Rules do not include a "heightened pleading standard for employment discrimination suits"); Crawford-El v. Britton, 523 U.S. 574, 595 (1998) (discussing previous rejections of heightened pleading standards).

147. Crawford-El, 523 U.S. at 595.

148. Id.

149. Bell Atl. Corp. v. Twombly, 550 U.S. 544, 569 n.14 (2007). 
reluctance to promulgate a ubiquitously heightened standard from the bench.

Because there are both judicial and legislative elements involved in amending the Federal Rules, ${ }^{150}$ this discussion stands apart as a sort of hybrid. To be sure, it is largely influenced by the judicial sector. "Judicial," in this sense, means judges, lawyers, and academicsindividuals who day in and day out observe trends in practice and in theory. The power to amend the Federal Rules is found in the Rules Enabling Act, first adopted in 1934, which states, "The Supreme Court shall have the power to prescribe general rules of practice ... for cases in the United States district courts ... and courts of appeals." ${ }^{\text {151 The }}$ process of amendment begins with the Judicial Conference's recommendation of a rule change to the Supreme Court. ${ }^{152}$ This rule is considered by the Advisory Committee, composed of judges, lawyers, and academics, which either approves or rejects the proposal. ${ }^{153}$ If approved, the proposals are evaluated by the Standing Committee on Rules of Practice and Procedure appointed by the Chief Justice of the Supreme Court. ${ }^{154}$ It is then reviewed by the Judicial Conference, which forwards it to the Supreme Court, which, upon its approval, sends it to Congress, where it will become law unless that body exercises its veto power within seven months. ${ }^{155}$

The input of judges, lawyers, and legal academics would be of great value to any revision of the pleading rules. To the extent that judges' past attempts at approving a heightened pleading standard for certain causes of action were rooted in an effort to screen meritless claims, their input is of obvious value in the amendment process. Judges, as well as practitioners, know the practical challenges facing the court as an institution in matters of judicial economy and docket control. Also, adequate public involvement is permitted through open hearings, invitations, and solicitations of participation. ${ }^{156}$

There are three ways, or a combination thereof, in which the Federal Rules could be amended to resolve the current pleading issue. First,

150. See Friedenthal ET AL., supra note 20, at 407 (citing Robert Bone, The Process of Making Process: Court Rulemaking, Democratic Legitimacy, and Procedural Efficacy, 87 GEO. L.J. $887,888,892(1999))$.

151. 28 U.S.C. $\$ 2072$ (a) (2006).

152. Bone, supra note 150 , at 892 .

153. Id.

154. Id.

155. Id.

156. Bone, supra note 82 , at 38-39 (noting the insulation of the rulemaking committees from political pressure). 
there could be an amendment that uses language to exact a pleading requirement in Rule 8 which clarifies or negates the notion of plausibility in the current standard. Second, there could be an amendment to Rule 9 to capture certain causes of action where plausibility or a similarly heightened standard should apply, like antitrust. Third, Rules 16 (case management), 26 (regarding pretrial disclosures), and 27 (regarding perpetuating testimony) could be revised and emboldened to allow more equitable case screening by the judiciary through management of presuit discovery that ferrets out frivolous claims.

The attractiveness of amending Rule 8 to clarify the current standard is that any language accomplishing it would, in tone with current language, likely remain brief and facially understandable. However, further examination would likely reveal the same linguistic ambiguities that "short and plain" have presented, as well as the vagueness of the current plausibility standard. ${ }^{157}$ Articulation of a more complex standard would be contrary to the idea that pleading should be accessible to the everyday litigant and a simple matter of notice.

The second way is to amend Rule 9(b) to encompass the types of litigation in need of a heightened standard. Yet a claim-specific standard would conflict with Rule 1, which states that the scope and purpose of the Federal Rules is to "govern the procedure in all civil actions and proceedings." "158 Additionally, the reasons that Rule 9 exists"protection of reputation, deterrence of frivolous or strike suits, defense of completed transactions, and providing adequate notice" 159 - do not comport with the purpose of providing uniform clarity. For these reasons, those involved in the amendment process may be hesitant to endorse more specific causes of action that fall under a heightened standard via the Federal Rules. Doing so would be an unruly taskcertain types of claims will not always embody the kinds of facts necessary for heightened pleading under Rule 9's "fraud or mistake" language. As already noted, a wide range of factual pleading requirements already seem to exist for certain types of litigation. ${ }^{160}$ Rule 9(b)'s language was meant to encompass common-law fraud claims that are quite different from modern fraud claims, like securities fraud. ${ }^{161}$

Reducing these causes of action into a Federal Rule would be difficult for a couple reasons. First, the causes of action that may be

157. See supra Part III.A.4.

158. FED. R. Civ. P. 1 (emphasis added).

159. Christopher M. Fairman, Heightened Pleading, 81 TEX. L. REV. 551, $562-67$ (2002).

160. See Fairman, supra note 22, at 989.

161. Fairman, supra note 159, at 608. 
subject to the amended rule vary so greatly that it would be impracticable to craft a single rule. ${ }^{162}$ Secondly, many causes of action that might fall under the rule, like antitrust, are based on statutes that are subject to legislation. Such legislation could be amended but that would necessitate an amendment to the Federal Rules, and an unworkable and impractical system. Additionally, finding language suitable to encompass modern statutory fraud claims would suffer from the same simplified language problem as Rule 8 .

The third option is to amend case management and discovery rules to allow for more equitable screening of cases. Insofar as courts do not construe Rule 27 liberally, it could also be amended to enable litigants to more easily pursue limited discovery to deal with a specified set of claims where the plaintiff cannot reasonably be expected to have the necessary facts to supplement allegations.

Several scholars have argued that under the current standard, fairness reasons justify allowance for minimally intrusive presuit discovery. ${ }^{163}$ The use of minimally intrusive discovery should be allowed in circumstances where, in the court's judgment, the plaintiff could not have reasonably been expected to access such facts necessary for the requirement. The judiciary's judgment would allow courts to ferret out what they view as a fishing expedition in favor of more wholesome claims. Generally, this notion is congruent with Federal Rule 16, which gives the court broad case management abilities. ${ }^{164}$ Another proposed supplemental policy that would help sort claims before the court is to shift the costs, or a fraction of the costs, to the plaintiff. ${ }^{165}$ Such a policy would need to be tempered to find a burden that would not be so heavy as to prevent plaintiffs from bringing suits, even if their merits were worthy, or so weak as to sustain the frivolity of plaintiffs to bring a meritless claim.

Practically, amending discovery rules may be an easier task than pleading rules. The brevity of the current pleading rules suggests an effort to keep things uniform and simple. This effort is in line with the traditional notice theory, but nonetheless quite complicated and more controversial. Conversely, discovery rules are extensive and detailed to account for the various discovery methods and to prevent their abuses. This provides an avenue for more explicit guidance to the judiciary and

\footnotetext{
162. See generally Fairman, supra note 22 (detailing the causes of action to which a heightened standard of pleading has been applied).

163. See Bone, supra note 24 , at $900-06$.

164. FED. R. CIV. P. 16.

165. See Bone, supra note 24 , at 928 .
} 
practitioners. While the effect of amending discovery rules means imposing a higher adaptive curve on the judiciary and practitioners, both have made such adjustments before.

Additionally, the use of presuit discovery is beneficial to both parties. If implemented, the role of the judge in defining "plausibility" is circumvented, providing for more effective screening and adequate assessment of seemingly nonmeritorious claims. In multi-defendant litigation, such discovery can provide an economical benefit by preventing some parties from having meritless claims brought against them and narrowing the field of defendants.

Generally, this rulemaking process would shield the proposal from interest-group influence and devious political pressures to a greater extent than congressional legislation. ${ }^{166}$ It is also likely to be a less politically charged issue because it addresses the Twombly-Iqbal paradigm more discreetly. Rather than amending the rules causing controversy in those cases, it changes rules that promise benefit for both parties in litigation. Amending discovery and case management practice under the Federal Rules is the best of the three options considered. Absent such amendments, the next best alternative is claim-specific legislation.

\section{Legislative Remedies}

As mentioned in Part II.B, Twombly and Iqbal concerned complex claims and legal issues, but managed to raise the pleading standard for all civil actions. This judicial process has had the effect of what one scholar likens to a "Cadillac process ... . [that] helps to drive out of federal court those who can afford only a Ford." ${ }^{, 167}$ Decisions concerning such policyrelated issues, like access to courts, are properly left to the formal rulemaking bodies like the legislature or those involved in the rule amendment process. These processes ensure adequate input and contribution from the legal community. A statute that clears the confusion about the pleading standard may be preferable for several reasons. Principally, the law would be democratic in its representation of the will of the people and would draw on testimony from the judiciary and legal scholars to create a less confusing and more viable standard. The legislative process would ensure that all parties were heard,

\footnotetext{
166. See Bone, supra note 82 , at 38-39 (noting the insulation of the rulemaking committees from political pressure).

167. See Burbank, supra note 92, at 563.
} 
accounting for and accurately reflecting societal and judicial needs. ${ }^{168}$ In accommodating public input on these matters, the public would have increased confidence in the judiciary, which is increasingly viewed as a product "not only of the political process, but of ordinary politics."169

A few legislative options exist to improve the current standard. First, Congress could enact legislation that substantiates a claim-specific standard for an area or a related range of areas. These standards could be more stringent, like Rule 9, or be in the mold of PSLRA's pleading standard. ${ }^{170}$ Second, Congress could, as it is currently contemplating, enact legislation that returns to the pre-Twombly and Iqbal standard, by making clear the threshold by which 12(b)(6) motions will be granted or the standard by which claims will be allowed under Rule 8 .

To some extent, Iqbal affirmed the direction that lower federal courts were already headed in after Twombly. ${ }^{171}$ Many pre-Iqbal opinions read Twombly as being generally applicable to all federal cases. ${ }^{172}$ For example, cases involving religious discrimination, ${ }^{173}$ Federal Housing Administration violation, ${ }^{174}$ and employment discrimination ${ }^{175}$ all applied Twombly's standard prior to Iqbal. This suggests some courts may have viewed the application of a newer, heightened standard as overdue and necessary for judicial efficiency. Such partiality signals a judicial perception that something needs to be done to combat frivolous claims that burden not only the court but other litigants. Because the cases that typically impose such burdens involve more complex claims, a specific legislative standard for them may be a viable alternative.

\section{Legislation Prescribing Claim-Specific Standards}

As noted in Part II, supra, resistance to notice pleading in various areas of the law existed prior to Twombly's overruling of Conley and Iqbal's extension to all civil actions. ${ }^{176}$ This resistance was present in the

168. See Bone, supra note 24, at 935-36 (asserting that regulation of court access is best suited for "a process open to public input, able to generate and properly consider relevant empirical information, and capable of addressing the issues from a global and systemic perspective").

169. Burbank, supra note 92, at 563-64.

170. See FED. R. Civ. P. 9(b) ("In alleging fraud or mistake, a party must state with particularity the circumstances constituting fraud or mistake.").

171. See Spencer, supra note 6, at 458-59 \& n.150 (citing several federal district court cases using "plausibility" outside of an antitrust context).

172. Id. at 458 .

173. Watts v. Fla. Int'l Univ., 495 F.3d 1289, 1296 (11th Cir. 2007)

174. Boykin v. KeyCorp, 521 F.3d 202, 213 (2d Cir. 2008).

175. Tamayo v. Blagojevich, 526 F.3d 1074, 1082-83 (7th Cir. 2008).

176. See generally Fairman, supra note 22 (detailing signs of heightened pleading beyond 
years following the implementation of the pleading system, but, after Conley, notice pleading ended the speculation about whether the liberal rules were genuine in application. ${ }^{177}$ At times, courts challenged its application in various contexts; at other times, legislative action would alter pleading standards for specific types of claims. The latter was the case with the Private Securities Litigation Reform Act (PSLRA) passed by Congress in 1995, over presidential veto, to combat frivolous lawsuits in the private securities arena. ${ }^{178}$ Since its inception, PSLRA has received its share of criticism. ${ }^{179}$ These negative reviews largely center around deciphering the heightened scienter requirement and confusing legislative history. ${ }^{180}$ Such criticisms could be particular to the securities fraud context and should not deter future pleading legislation.

The enactment of PSLRA came after industry groups complained of frivolous "sue now, discover later" suits, comparable to the one in Twombly, that classes of plaintiff investors were entitled to file. ${ }^{181}$ Congress required that plaintiffs plead misleading statement and omission claims with particularity as well as conforming with the scienter requirement. ${ }^{182}$ Discovery is also not allowed while a motion to dismiss is pending. ${ }^{183}$ The application of PSLRA has received criticism similar to Iqbal in that it requires a plaintiff to plead facts only the defendant possesses, without the benefit of some kind of discovery. ${ }^{184}$ These mishaps of the PSLRA and its application should serve as lessons for lawmakers.

Legislative reform is preferable to judicial analysis from the bench. As already noted, reliance on binding judicial interpretation and precedence is not an efficient and resourceful way to go about changing the standard when it implicates greater policy and social concerns. Iqbal's civil rights action is a primary illustration of one such concern. Cases that have the effect of adjudicative policymaking lack the educated and needed input of lower court judges, practitioners, academics, and the public, making it generally undemocratic.

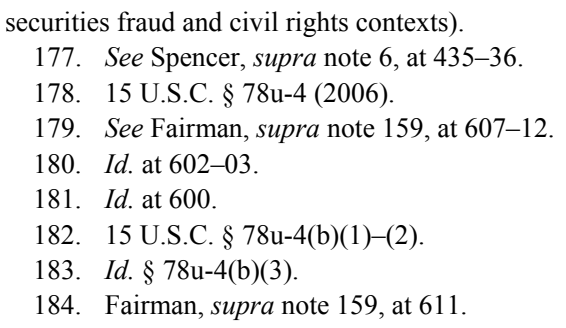




\section{Returning to Conley: Notice Pleading Restoration Act of 2009}

The Notice Pleading Restoration Act of 2009 or, alternatively, the Access to Open Courts Act of 2009, proposes to retract the current judicial interpretation of Rule 8(a) and essentially restore the application of Conley to 12(b)(6) motions. The success of that bill's current language is unlikely because of the simplicity of the standard. Reverting back to Conley for all civil actions would reflect a poor assessment of the modern demands of litigation. As illustrated by Twombly, allowing plaintiffs to impose exorbitant discovery costs on defendants by way of a claim that does not withstand judicial plausibility is unjust. Another perceived hurdle to such legislation is the political clout among interest groups favoring the standard that may be exerted to influence legislators. The perception of "anemic" claims withstanding judicial scrutiny will bolster the opposition of economically powerful organizations like corporations. Of course, groups advocating liberal notice pleading-the plaintiff's bar and civil rights organizations like the NAACP-will also be heard. Such participation is appropriate because of the political stakes. These competing interests signify one benefit of the proposed legislation in that it makes this core democratic issue more publicized and provides more opportunity for public input, generating a more productive discussion.

However, any compromise that reflects the needs of modern litigation is unlikely under the Bill's current language that promotes "the standards set forth by the Supreme Court of the United States in Conley v. Gibson." $" 185$ It is not likely that the simplicity of the language will generate the extended discussion necessary to account for current complex litigation needs of the type encountered in Twombly.

Some commentators have already weighed in on the legislation. One proposes a redraft of the bill to include much of the language that refutes the language used in Twombly and Iqbal:

[A] Federal court shall not deem a pleading inadequate under rule 8(a)(2) or rule 8(b)(1)(A) of the Federal Rules of Civil Procedure, on the ground that such pleading is conclusory or implausible, except that a court may take judicial notice of the implausibility of a factual allegation. So long as the pleaded claim or defense provides fair notice of the nature of the claim or defense, and the allegations, if taken to be

185. S. 1504,111 th Cong. (2009). 
true, would support a legally sufficient claim or defense, a pleading satisfies the requirements of rule $8 .^{186}$

This proposed standard is more defendant-friendly because it addresses complaints under Rule 8, in addition to $12(\mathrm{~b})(6)$ motions. The proposal also attempts to rebut the plausibility standard. Yet, it still employs much of the same language as the current standard and allows for a court to take "notice of the implausibility of a factual allegation." 187 Retaining this language will not remedy the standard's current inconsistency and lack of clarity.

If the Bill were to pass in its current form, it is very possible claimspecific legislation may follow. The same benefit may have accrued had Twombly been decided the other way. Those defendants most likely affected, like corporations, would respond by advocating a heightened standard. A surer path to accommodating fair and efficient pleading would be to confront the problem with claim-specific legislation from the outset.

\section{E. Recommendation}

The two best remedies for the current state of pleading doctrine are the amendment of the Federal Rules to provide for equitable case screening or Congress's enactment of claim-specific legislation. An amendment allowing minimally intrusive discovery and reinforcing equitable case management to decrease dismissal of meritorious claims is the most feasible and practical alteration of the Federal Rules. The best way to go about this is to insert language into the Federal Rules that articulates greater judicial discretion in certain circumstances to allow for limited discovery in limited circumstances. Ideally, such a measure would affect the type of action brought by far removed plaintiffs like Javaid Iqbal. More language using equitable terms like "undue prejudice" or "in the interests of justice" is one step toward granting the needed discretion.

The ability of the amendment process to provide public input is highly valued because analyzing a proposed standard involves a thorough empirical and theoretical survey of the current judicial landscape. It could involve heavy costs-benefits scrutiny common to public policy analysis. Since part of the judicial justification for

\footnotetext{
186. Mike Dorf, Dorf on Law Blog (July 29, 2009) (emphasis added), available at http:// www.dorfonlaw.org/2009/07/alternative-to-senator-specters-notice_28.html.

187. S. 1504.
} 
heightened pleading is economic (assessing economics of pleading practice and cost-shifting analyses), a comprehensive survey of cases and litigation costs will need to be considered. Academics and institutional scholars are the most ideal lot for such an empirical task. The ability of a wronged person to "have their day in court" is a serious matter that goes to the heart of our democracy.

Legislation that assigns heightened standards to those causes of action Congress deems ripe for such a standard is the best of the purely legislative alternatives. The fact that both Twombly and Iqbal were cases involving highly complex claims in complex organizational contexts is significant because it is precisely these areas where claim-specific legislation would have the greatest effect. However, such legislation still poses the question of what to do with other cases still subjected to the plausibility standard. Absent a clarification of this issue or a circumvention of it, like more equitable case management, legislation is simply not enough. The process of amending the Federal Rules ensures more logical language and ease in application. Additionally, legislative reform may be unlikely to attract adequate public attention, especially among matters such as healthcare and Afghanistan, and may not generate a meaningful legislative process.

\section{CONCLUSION}

The current state of pleading doctrine places some plaintiffsparticularly far-removed plaintiffs - in an unjust place that is contrary to democratic principles. While the advantages of economic and judicial efficiency have seemingly been at the forefront of modern pleading reform, such priorities are at odds with the declared purpose of pleading under the Federal Rules. No doubt these concerns are worthy, but at what cost? Are the complexities of society and desire for judicial economy enough to justify modern pleading doctrine? For the sake of those suffering the improprieties of others, often the powerful, such justifications are improper. The best solution to the plausibility problem would be amending the Federal Rules to allow for more efficient case management early in the lawsuit and limited discovery to test good-faith conclusory allegations. This path avoids the ambiguous language problems of the plausibility standard and, politically, is likely to have more success than other amendment alternatives. Alternatively, claimspecific legislation that imposes heightened standards for those causes of action most associated with economic and judicial inefficiency is a viable remedy for the application of the current standard. 
In the wake of Twombly, Iqbal made it harder for not only farremoved individuals suffering from information asymmetry, but also those closely engaged with their adversaries, to bring a complaint that would survive the pleading stage. ${ }^{188}$ The extension of plausibility pleading is too strict and at odds with the traditional notion of notice pleading. Further, litigants suffer from a lack of clarity in this evolving pleading standard. Such imprecision can create higher transactional costs and burdens for both parties - a result at odds with the notions of judicial and economic efficiency that were behind Twombly. Iqbal's reach to all civil actions could have other procedurally inefficient implications, like defendants seeking a federal venue or a particular state venue to avail themselves of a favorable application of the current standard. The ability of the judiciary to provide a clearer definition than plausibility and allow for minimally intrusive discovery under current law is limited.

Absent formal rulemaking, action by the judiciary will be inefficient. Thus, legislative action is the preferred method of remedying the negative effects of Twombly and Iqbal. Pleading standards are a question of policy that is best left to the formal rulemaking process promulgated under the Rules Enabling Act or through legislation. Access to courts is too important in our democracy not to conform to the democratic will.

188. See Ashcroft v. Iqbal, 129 S. Ct. 1937, 1953 (2009) (noting that a plausibility standard applies to all civil actions under Federal Rule 1). 